\title{
POLITICAL PATRONAGE AND CORPORATE LEVERAGE: EVIDENCE FROM VIETNAMESE LISTED FIRMS
}

\author{
ANH T. P. HOANG ${ }^{1}$, ANH D. PHAM ${ }^{2}$ \\ ${ }^{1}$ School of Finance, University of Economics Ho Chi Minh City, Vietnam \\ ${ }^{2}$ Research Institute for Banking, Banking Academy, Hanoi, Vietnam \\ anhtcdn@ueh.edu.vn,anhpd@hvnh.edu.vn
}

\begin{abstract}
Since the open-door policy of 'Doi Moi' was launched in 1986, Vietnam has made great strides, from among the world's most impoverished nations to a lower middle-income country. During the development process, there is a growing tendency towards the co-operation between the public and private sectors with the emergence of state-owned and state-controlled enterprises. Previous literature have shown that politically patronised firms tend to gain better access to credit markets than others, owing to either established connections with financial intermediaries or state influence within major banks. This study explores the difference in capital structure between politically patronised and non-connected firms. Applying difference-in-differences approach to a panel dataset of 160 Vietnamese publicly listed companies over the period 2006-2015, empirical results indicate that politically patronised firms tend to hold significantly higher levels of debt than non-connected ones. Besides, taking an exogenous shock, namely the 2008 financial crisis, into consideration, the above results still remain true during the crisis as well as post-crisis period.
\end{abstract}

Keywords. corporate leverage, difference-in-differences model, emerging market economies, political patronage.

\section{INTRODUCTION}

Vietnam has currently been rated as among the fastest growing economies in Asia. From one of the most impoverished nations in the 1980s, it has been rising fast to become a lower middle-income country. In the past, Vietnam has followed a centralized economic model where the state fully owns production and business activities - the economy focuses on agriculture and heavy industry. At that time, Vietnam's economy was in the state of hyperinflation and financial crisis. Therefore, in 1986 the Government of Vietnam decided to adjust economic policies, transforming from a centralized economy to a multi-sector economy. During the reform process, the economy has appeared many economic sectors and the economic model commanded by the state. The connection between the state and enterprises is reflected in the existence of many state-owned enterprises and enterprises with state-contributed capital. According to statistics of Vietnam Chamber of Commerce and Industry (VCCI), in 2014, up to 95\% of businesses operating in Vietnam are small and medium enterprises, yet, only $15 \%$ of which could have access to formal credit. Meanwhile, state-owned enterprises or enterprises with state-owned shareholders are more easily accessible to the capital market because most of the state-controlled enterprises are close and close customers with banks. Owing to these relationships, Vietnamese enterprises with a significant proportion of state ownership might have better access to loans from banking corporations regardless of their performance and repayment capacity [23]. Furthermore, state-owned enterprises, with strong endorsement from the government, might be given a higher priority in accessing debt at low costs. As a result, they can use more debt than other businesses, ceteris paribus. Thus, we argue that the relationship between political patronage and corporate levarage is an issue of great concern, yet has not been studied or discussed intensively in Vietnam. To our best knowledge, researchers, namely [23] and [25], found conflicting results on the effects of state ownership on the capital structure for the case of Vietnamese publicly listed companies, though the differences in the research sample are negligible. This clearly stresses the importance of the assessment of the link between the state and the businesses, i.e. political patronage, in typically emerging market economies such as Vietnam.

This study focuses on examining the impact of political connections on corporate financial decisions. Besides, during periods of economic instability, the close relationship between borrowers and borrowers becomes crucially important ([2]). Therefore, state-backed businesses are more likely to borrow and hold more debt than firms without political endorsement during crisis periods. However, the unofficial 
government sponsorship may be reduced by the ferocious nature of a crisis if the crisis increases the systemic risk and causes insecurity to authorities and the government ([11]; [17]). To clarify this issue, the present paper also explores whether the financial decisions of enterprises differ in the crisis period from the later recovery period, and how effective political patronage could be during each stage.

\section{LITERATURE REVIEW}

\subsection{The impact of financial leverage on performance}

It is admitted that the effect of political patronage on various different financial aspects of firms has caught attention from an enormous number of researchers. Nevertheless, scholarly literature concerning its impact on capital structure decisions of firms seems rather scarce. By and large, the empirical results provide evidence in favor of the positive effect of political connections on corporate debt with the proposition that "more politically related, more highly leveraged".

[4] study of politically protected businesses for a sample of 47 countries suggests that the links between politicians and businesses are quite common. This relationship exists in countries with limited foreign investment, countries with corruption problems and in countries with transparent economies and open doors. Protected businesses will have certain benefits compared to other businesses: preferential treatment by state agencies; lighter tax system; and more legal oversight for protected businesses.

Research by [7] on capital structure and political patronage for enterprises listed on KLSE (Kuala Lumpur Stock Exchange) over the period from 1990 to 1999 with the null hypothesis that these politically patronised ones tend to use more debt. In line with this, empirical results indicate a positive and statistically significant correlation between corporate leverage and political connections. Aside from that, [7] also proved the indirect association between political patronage and leverage through firm size and profitability characteristics. That is, along with political patronage, larger enterprises would be likely to use more debt. Likewise, profitable politically connected firms tend to use more debt than purely patronised ones. In addition, corporate leverage is found to have a positive association with firms' size, profitability and tangible fixed assets.

[15] also support the school that there exists a positive correlation between state ownership and debt ratio. In this study, the author applied panel data regression to examine the impact of state ownership on the debt decision of listed companies on the Chinese stock market. Research results show that there exists a positive relationship between state ownership, measured by the ratio of state holdings and corporate leverage, measured separately by either total debt ratio, short-term debt ratio and long-term debt ratio. Accordingly, [15] argued that firms with a high state-shareholding ratio tend to use more debt owing to special endorsement from the state.

In an attempt to explore the relationship between political linkage and corpoate leverage on the sample of the largest 500 non-financial listed firms in Malaysia between 2001 and 2004, [1] found that leverage ratio is positively correlated with political linkages, firm size, assets, land and equipment, market-to-book ratio, yet, negatively correlated with ROA. These authors argued that since businesses are backed by the government, both state-owned banks and other commercial banks have incentives for these patronised businesses, i.e. both approved loans with ease (reflected in irresponsible appraisal process) for government-backed businesses even if they pose high credit risks.

The study of [16] examines the impact of political patronage on the capital structure of companies listed on Shanghai stock exchange over the period 2009-2011. Empirical findings point to a clear association between state ownership and investment structure, specifically: (i) government subsidized companies have a positive correlation with capital structure; (ii) effective tax rates of listed companies is unrelated to its capital structure; (iii) companies with better access to bank credit have higher degree of debt usage. The results demonstrate that state connections greatly assist patronised companies in absorbing long-term loans from banks since the banking industry is, more or less, under the state control.

Research by [21] on political linkages, management structure and bank loan preferences for a sample of Taiwanese listed companies in the period 1998-2006 reveals that political patronage has a positive link with bank loan preferences, but there are still differences depending on the ruling party in Taiwan. 
Research by [14] on political links, financial crisis and firm value for Chinese listed enterprises shows that political links have both positive and negative effects on firm value. Meanwhile, net asset value per share of patronised firms has a positive impact on the firm value. However, growth opportunities of politically connected firms have insignificant impact on firm value. Besides, political connections are found not to have a significant impact on the long-term growth opportunities of businesses. The impact of political patronage alters as exogenous shocks arise. In the period 2006-2007, political patronage had no significant impact on firm value, howver, turning into the post-crisis period of 2009-2010, the impact became evident. Thus, the study has shown that there exists a difference between the impact of political patronage between the pre- and post- 2008 financial crisis.

[22] evaluate the impact of political patronage on financial accessibility and performance of Indonesian businesses. As defined in this study, political patronage is made up of state ownership in businesses, the involvement of politicians on board and senior managers of companies that have relationships with politicians. Empirical results show that companies that are protected by politics are more likely to borrow from state-owned banks. Moreover, being protected by the government increases the opportunity that a company may receive the full amount of bank loans they apply for. The effect of political patronage on access to bank loans could be either positive or negative. On the positive side, obstacles in borrowing and asymmetry information of patronised companies seem lower than nonconnected ones since the former tend to be closer with the bank officials, thus conveying the necessary information about reliability to these officials. On the negative side, as bankers are corrupt and offer bribes to approve loans, companies with political ties could receive less bribes, thus paving the way for less wỏthy loans to be approved. Political patronage might help improve access to finance of small and medium enterprises rather than large ones. In addition, it seems likely that improvement of debt payment capacity would be deriving from relationships with politicians rather than from government ownership or politicians in the board.

Derived from [1] study, [24] extended the study period from 2002-2015 to investigate the impact of political connections on the cost of debt among Malaysian companies. Research results show that companies with political endorsement tend to have lower debt costs. In addition, the author also found that the binary CEO variable (CEO playing a dual role as executive director and board chair) is linked to higher debt costs. Third, higher degree of independence of the audit committee might lead to lower debt costs. Though empirical results are consistent with theoretical and empirical literature, [24] suggested that in order to judge the impact of political patronage precisely, a far longer timeframe should be utilised to capture all changes in the firm leadership.

\section{METHODOLOGY}

\subsection{Data}

The study employs data from annual financial statements of Vietnamese enterprises listed on the HNX and HOSE stock exchanges between 2006 and 2015. After eliminating financial and utilities businesses, as well as those starting listing after 2007, our final sample consists of 160 businesses. Secondary data is collected from Thomson Reuter's DataStream.

\subsection{Empirical model}

The study employs difference-in-differences (DID) approach to empirically examine the impact of political patronage on corporate financial decisions. DID framework is designed to compare the differences between two target groups, one known as the 'treatment group' (leverage ratio of politically patronised firms) and the other one as the 'control group' (leverage ratio of non-connected firms). To illuminate this issue, we construct our model containing two sub-periods: (i) 2008-2009, representing the crisis period, and (ii) 2010-2015, capturing the recovery phase ([10]). Accordingly, the research model is written as follows:

Leverage $_{i t}=\beta_{1} * D_{i}+\beta_{2} * E_{l t}+\beta_{3} * E_{l t} * D_{i}+\sum \beta_{l} X_{i t-1} * E_{l t}+\sum \beta_{k} X_{i t-1} * E_{l t} * D_{i}+\beta_{22} * E_{2 t}+$ $\beta_{33} * E_{2 t} * D_{i}+\Sigma \beta_{m} X_{i t-1} * E_{2 t}+\Sigma \beta_{j} X_{i t-1} * E_{2 t} * D_{i}$ 
Where:

- Leverage is the ratio of leverage is the ratio of total debt to total assets.

- $\mathrm{D}_{\mathrm{i}}$ is a proxy for political patronage. Based on the study of [3], there are three methods of determining political protection in enterprises. First, political patronage is defined, according to [8], to be an informal connection between politicians and businesses in terms of individuals (businesses there are shares held by friends, relatives of politicians, or held by the politicians themselves but through another representative). Second, the assessed enterprises are operating under political protection when they are controlled by state investment funds such as the Khazanah Nasional Berhad fund of Malaysia or the State Capital Investment Corporation (SCIC) of Vietnam. Third, there exists an investor in the enterprise that is protected by the government. However, due to shortages of data and information in Vietnam, this study combines the second and third methods to classify businesses that are protected by the state. Following this method, the political patronage variable receives the value of 1 if SCIC or a government-sponsored business has a state ownership ratio equal to or greater than $51 \%$, and 0 otherwise.

- $\mathrm{E}_{1 \mathrm{t}}$ equals 1 corresponding to the financial crisis period (2008-2009), and 0 otherwise.

- $\mathrm{E}_{2 \mathrm{t}}$ equals 1 in case of the recovery period (2010-2015), and 0 otherwise.

- $\mathrm{X}$ are variables measuring the characteristics of an enterprise that have an impact on the debt ratio such as firm size (measured as logarithm of total assets), profitability (measured as the ratio of EBIT to total assets), tangible assets (Tangibility), growth potentials (measured by the market-to-book value ratio of the equity), industry average leverage (measured as the debt-to-assets ratio of peers), cash flow volatility (measured as the ratio of ROA to its standard deviation).

Coefficient $\beta_{1}$ measures the degree of difference between the leverage ratio of the protected enterprise and the remaining enterprises over time. According to previous studies, it is found that businesses that are protected by politics with more debt than not too much, this leads to an expectation of $\beta_{1}>0$. The coefficient $\beta_{2}$ indicates the reaction of blow rate seven of Vietnamese enterprises in the period of 2008-2009 compared to the pre-crisis period. Positive (negative) $\beta_{2}$ indicates higher (lower) debt. The coefficient $\beta_{22}$ indicates the reaction of leverage ratio of Vietnamese enterprises in the period of 20102014 compared to the pre-crisis period. Given that Vietnamese enterprises hold less debt levels in the post-crisis period because of the development of capital markets or to reduce issues related to agency costs, it is expected that $\beta_{22}<0 . \beta_{3}$ is the interaction coefficient between $D_{i}$ and $E_{1 t}$ and the measure of the impact of exogenous shock on the leverage of protected enterprises in the period of 2008-2009. $\beta_{33}$ is the interaction coefficient between $\mathrm{D}_{\mathrm{i}}$ and $\mathrm{E}_{2 \mathrm{t}}$, measuring the impact of exogenous shock on the leverage of protected businesses in the period 2010-2014.

The study combines $E_{1 t}$ and $E_{2 t}$ with business characteristics to justify how these variables affect leverage at each stage. The coefficients $\beta_{1}$ and $\beta_{\mathrm{m}}$ measure the impact of characteristic variables of enterprises in the post-crisis period and during the crisis period. To judge whether political patronage affects the relationship between business characteristic variables and leverage, each of those interactions will be combined with $D_{i}$ - reflected through coefficients $\beta_{k}$ and $\beta_{j}$.

\section{RESULTS AND DISCUSSION}

\subsection{Summary statistics}

Table 1 presents the summary statistics of the variables. The number of observations for businesses that are protected is moderate (notably, there is no observation in two sectors, namely technology and oil and gas). In general, the average leverage ratio of politically connected companies is higher than that of the non-connected in all sectors, of which telecommunications, transportation, warehousing and logistics witnessed particularly large differentials. This proves that in Vietnam, political sponsorship seems to have insignificant impact on the enterprises' ability to use leverage. On the other hand, our descriptive statistics initially support conclusions of the earlier studies, that politically patronised firms would be likely to hold higher degrees of debt ([7]; [1]; [3]). 

VIETNAMESE LISTED FIRMS

Table 1: Descriptive statistics

\begin{tabular}{|c|c|c|c|c|c|c|c|c|}
\hline Sector & Obs & Leverage & Size & Profitability & Growth & Tangibility & Industry & Volatility \\
\hline \multicolumn{9}{|l|}{$\begin{array}{l}\text { Non politically } \\
\text { connected firms }\end{array}$} \\
\hline Telecommunications & 58 & 0.387 & 95.774 & 0.103 & 0.677 & 0.103 & 0.461 & 1.074 \\
\hline Technology & 16 & 0.491 & 170.248 & 0.104 & 0.623 & 0.121 & 0.561 & 1.195 \\
\hline Oil and gas & 53 & 0.437 & $5,384.371$ & 0.162 & 1.029 & 0.280 & 0.633 & 1.739 \\
\hline Consumer goods & 52 & 0.233 & 769.726 & 0.195 & 1.251 & 0.173 & 0.453 & 2.371 \\
\hline Consumer services & 125 & 0.522 & 673.993 & 0.091 & 0.622 & 0.118 & 0.642 & 0.826 \\
\hline Industrials & 568 & 0.417 & $1,089.110$ & 0.110 & 1.928 & 0.232 & 0.506 & 1.105 \\
\hline $\begin{array}{l}\text { Transportation, } \\
\text { warehousing and } \\
\text { logistics }\end{array}$ & 125 & 0.392 & $1,228.871$ & 0.111 & 0.742 & 0.383 & 0.520 & 1.138 \\
\hline $\begin{array}{l}\text { Construction and real } \\
\text { estate }\end{array}$ & 192 & 0.644 & $1,101.373$ & 0.071 & 0.703 & 0.111 & 0.696 & 0.560 \\
\hline \multicolumn{9}{|l|}{$\begin{array}{l}\text { Politically connected } \\
\text { firms }\end{array}$} \\
\hline Telecommunications & 9 & 0.538 & $11,885.690$ & 0.179 & 1.397 & 0.111 & 0.549 & 1.898 \\
\hline Technology & - & - & - & - & - & - & - & - \\
\hline Oil and gas & - & - & - & - & - & - & - & - \\
\hline Consumer goods & 19 & 0.273 & 313.083 & 0.183 & 1.299 & 0.109 & 0.454 & 2.160 \\
\hline Consumer services & 17 & 0.597 & 791.577 & 0.108 & 0.552 & 0.094 & 0.685 & 0.775 \\
\hline Industrials & 126 & 0.574 & $2,026.050$ & 0.126 & 0.983 & 0.207 & 0.502 & 1.180 \\
\hline $\begin{array}{l}\text { Transportation, } \\
\text { warehousing and } \\
\text { logistics }\end{array}$ & 8 & 0.632 & $2,661.949$ & 0.072 & 0.696 & 0.855 & 0.605 & 0.444 \\
\hline $\begin{array}{l}\text { Construction and real } \\
\text { estate }\end{array}$ & 53 & 0.663 & 976.926 & 0.083 & 0.613 & 0.214 & 0.717 & 0.694 \\
\hline
\end{tabular}

\subsection{Research findings}

DID is a form of regression model with assumptions akin to OLS assumptions. It is assumed that the remainder must be independent of each other. In many cases due to the characteristics of the sample, the remainder of the observations in each group is not independent. To overcome this issue, regression can be performed with strong standard errors and cluster options. The idea of cluster regression methods is to make adjustments in estimates to overcome the disadvantages of data. With the regression method options with this strong standard error, the estimation of the coefficients in the equation will be the same as the normal regression of DID but the standard errors in this regression result have been considered. Change variance and normal distribution. Table 2 demonstrates the results from 5 models in 5 columns, in which column 1 is the result of DID regression model. To test the robustness of the estimated results, the paper uses a strong annual error (cluster) to control the chain correlation of the dependent variable for model estimation. Figure 2 and eliminate dummy crisis of $E_{1}$ and post-crisis $E_{2}$ to consider the impact of unobserved factors in normal conditions. For example, the level of leverage can be affected by institutional factors such as economic conditions, business cycles, legal environment, legal structure and economic growth rate. Next is model 4 created from model 2 and eliminating dummy political protection (D) to assess the impact of unobservable enterprise specific factors. Finally, remove the time dummy and the interaction variable between the industry average leverage and the dummy variable $E_{1}$ and $E_{2}$ from model 2, the model has built the model 5. Purpose of the model 5 is to control the sectoral fixed effects corresponding to each period but not observed in the model, with the assumption that these factors can cause differences in the debt ratio of enterprises. 
Table 2: Impact of political patronage on corporate leverage

\begin{tabular}{|c|c|c|c|c|c|c|}
\hline Variables & Coefficient & Model 1 & Model 2 & Model 3 & Model 4 & Model 5 \\
\hline $\mathrm{D}_{\mathrm{i}}$ & $\beta_{1}$ & $\begin{array}{c}0.121 * * * \\
(0.027)\end{array}$ & $\begin{array}{c}0.121 * * * \\
(0.038)\end{array}$ & $\begin{array}{c}0.130 * * * \\
(0.039)\end{array}$ & & $\begin{array}{c}0.129 * * * \\
(0.039)\end{array}$ \\
\hline $\mathrm{E}_{1 \mathrm{t}}$ & $\beta_{2}$ & $\begin{array}{c}-0.876^{* * * *} \\
(0.217)\end{array}$ & $\begin{array}{c}-0.876^{* * * *} \\
(0.283)\end{array}$ & & $\begin{array}{c}-0.894 * * * \\
(0.283)\end{array}$ & \\
\hline $\mathrm{D}_{\mathrm{i}} * \mathrm{E}_{1 \mathrm{t}}$ & $\beta_{3}$ & $\begin{array}{c}0.025 \\
(0.398)\end{array}$ & $\begin{array}{c}0.025 \\
(0.554)\end{array}$ & $\begin{array}{c}-0.829^{*} \\
(0.474)\end{array}$ & $\begin{array}{c}0.156 \\
(0.538)\end{array}$ & $\begin{array}{l}-0.819^{*} \\
(0.474)\end{array}$ \\
\hline Size $* E_{1 t}$ & $\beta_{11}$ & $\begin{array}{c}0.022 * * * \\
(0.008)\end{array}$ & $\begin{array}{c}0.022 * * * \\
(0.011)\end{array}$ & $\begin{array}{c}-0.009 * * * \\
(0.002)\end{array}$ & $\begin{array}{c}0.022 * * \\
(0.011)\end{array}$ & $\begin{array}{c}0.004 * * * \\
(0.001)\end{array}$ \\
\hline Prof $* \mathrm{E}_{1 \mathrm{t}}$ & $\beta_{12}$ & $\begin{array}{c}0.372 \\
(0.454)\end{array}$ & $\begin{array}{c}0.372 \\
(0.480)\end{array}$ & $\begin{array}{c}0.101 \\
(0.438)\end{array}$ & $\begin{array}{c}0.368 \\
(0.481)\end{array}$ & $\begin{array}{c}0.488 \\
(0.530)\end{array}$ \\
\hline Grow $* E_{1 t}$ & $\beta_{13}$ & $\begin{array}{c}-0.000 \\
(0.000)\end{array}$ & $\begin{array}{c}-0.000 \\
(0.000)\end{array}$ & $\begin{array}{c}-0.000 * * \\
(0.000)\end{array}$ & $\begin{array}{c}-0.000 \\
(0.000)\end{array}$ & $\begin{array}{c}-0.000 \\
(0.000)\end{array}$ \\
\hline Tang $* \mathrm{E}_{1 \mathrm{t}}$ & $\beta_{14}$ & $\begin{array}{c}0.098 \\
(0.065)\end{array}$ & $\begin{array}{c}0.098 \\
(0.084)\end{array}$ & $\begin{array}{c}0.094 \\
(0.083)\end{array}$ & $\begin{array}{c}0.097 \\
(0.084)\end{array}$ & $\begin{array}{c}0.030 \\
(0.091)\end{array}$ \\
\hline Ind $* E_{1 t}$ & $\beta_{15}$ & $\begin{array}{c}0.620 * * * \\
(0.071)\end{array}$ & $\begin{array}{c}0.620 * * * \\
(0.092)\end{array}$ & $\begin{array}{c}0.595 * * * \\
(0.091)\end{array}$ & $\begin{array}{c}0.619 * * * \\
(0.093)\end{array}$ & \\
\hline Vol $* \mathrm{E}_{1 \mathrm{t}}$ & $\beta_{16}$ & $\begin{array}{c}-0.118^{* * * *} \\
(0.042)\end{array}$ & $\begin{array}{c}-0.118^{* * * *} \\
(0.043)\end{array}$ & $\begin{array}{c}-0.106^{* * * *} \\
(0.039)\end{array}$ & $\begin{array}{c}-0.118 * * * \\
(0.043)\end{array}$ & $\begin{array}{c}-0.150 * * * * \\
(0.048)\end{array}$ \\
\hline Size $* E_{1 t} * D_{i}$ & $\beta_{\mathrm{k} 1}$ & $\begin{array}{c}0.003 \\
(0.017)\end{array}$ & $\begin{array}{c}0.003 \\
(0.023)\end{array}$ & $\begin{array}{l}0.034 * \\
(0.020)\end{array}$ & $\begin{array}{c}0.003 \\
(0.023)\end{array}$ & $\begin{array}{c}0.020 \\
(0.020)\end{array}$ \\
\hline Prof $* \mathrm{E}_{1 \mathrm{t}} * \mathrm{D}_{\mathrm{i}}$ & $\beta_{\mathrm{k} 2}$ & $\begin{array}{c}0.308 \\
(0.848)\end{array}$ & $\begin{array}{c}0.308 \\
(0.901)\end{array}$ & $\begin{array}{c}0.533 \\
(0.880)\end{array}$ & $\begin{array}{c}0.303 \\
(0.902)\end{array}$ & $\begin{array}{c}0.137 \\
(0.931)\end{array}$ \\
\hline Grow $* \mathrm{E}_{1 \mathrm{t}} * \mathrm{D}_{\mathrm{i}}$ & $\beta_{\mathrm{k} 3}$ & $\begin{array}{c}0.026 \\
(0.067)\end{array}$ & $\begin{array}{c}0.026 \\
(0.074)\end{array}$ & $\begin{array}{c}0.032 \\
(0.074)\end{array}$ & $\begin{array}{c}0.027 \\
(0.074)\end{array}$ & $\begin{array}{c}0.032 \\
(0.074)\end{array}$ \\
\hline Tang $* \mathrm{E}_{1 \mathrm{t}} * \mathrm{D}_{\mathrm{i}}$ & $\beta_{\mathrm{k} 4}$ & $\begin{array}{c}-0.179 * \\
(0.102)\end{array}$ & $\begin{array}{l}-0.179 \\
(0.134)\end{array}$ & $\begin{array}{l}-0.175 \\
(0.134)\end{array}$ & $\begin{array}{l}-0.179 \\
(0.134)\end{array}$ & $\begin{array}{l}-0.113 \\
(0.139)\end{array}$ \\
\hline Ind $* \mathrm{E}_{1 \mathrm{t}} * \mathrm{D}_{\mathrm{i}}$ & $\beta_{\mathrm{k} 5}$ & $\begin{array}{c}-0.251 * \\
(0.143)\end{array}$ & $\begin{array}{l}-0.251 \\
(0.185)\end{array}$ & $\begin{array}{c}-0.224 \\
(0.186)\end{array}$ & $\begin{array}{l}-0.250 \\
(0.186)\end{array}$ & $\begin{array}{c}0.371 * * \\
(0.163)\end{array}$ \\
\hline $\mathrm{Vol} * \mathrm{E}_{1 \mathrm{t}} * \mathrm{D}_{\mathrm{i}}$ & $\beta_{\mathrm{k} 6}$ & $\begin{array}{l}-0.013 \\
(0.084)\end{array}$ & $\begin{array}{l}-0.013 \\
(0.086)\end{array}$ & $\begin{array}{l}-0.021 \\
(0.084)\end{array}$ & $\begin{array}{l}-0.012 \\
(0.085)\end{array}$ & $\begin{array}{c}0.025 \\
(0.089)\end{array}$ \\
\hline$E_{2 t}$ & $\beta_{22}$ & $\begin{array}{c}-1.298 * * * \\
(0.120)\end{array}$ & $\begin{array}{c}-1.298 * * * \\
(0.221)\end{array}$ & & $\begin{array}{c}-1.316^{* * *} \\
(0.221)\end{array}$ & \\
\hline $\mathrm{D}_{\mathrm{i}} * \mathrm{E}_{2 \mathrm{t}}$ & $\beta_{33}$ & $\begin{array}{c}0.870 * * * \\
(0.266)\end{array}$ & $\begin{array}{c}0.870 * * \\
(0.414)\end{array}$ & $\begin{array}{c}-0.379 \\
(0.347)\end{array}$ & $\begin{array}{c}0.991 * * \\
(0.411)\end{array}$ & $\begin{array}{c}-0.372 \\
(0.349)\end{array}$ \\
\hline $\operatorname{Size}^{*} \mathrm{E}_{2 \mathrm{t}}$ & $\beta_{\mathrm{m} 1}$ & $\begin{array}{c}0.041 * * * \\
(0.005)\end{array}$ & $\begin{array}{c}0.041 * * * \\
(0.009)\end{array}$ & $\begin{array}{c}-0.004^{*} \\
(0.002)\end{array}$ & $\begin{array}{c}0.041 \text { *** } \\
(0.008)\end{array}$ & $\begin{array}{c}0.005 * * * \\
(0.001)\end{array}$ \\
\hline Prof $* E_{2 t}$ & $\beta_{\mathrm{m} 2}$ & $\begin{array}{c}0.880 * * * \\
(0.312)\end{array}$ & $\begin{array}{c}0.880 * * * \\
(0.422)\end{array}$ & $\begin{array}{c}1.255^{* * * *} \\
(0.448)\end{array}$ & $\begin{array}{c}0.880 * * * \\
(0.422)\end{array}$ & $\begin{array}{c}1.406^{* * * *} \\
(0.472)\end{array}$ \\
\hline Grow $* E_{2 t}$ & $\beta_{\mathrm{m} 3}$ & $\begin{array}{c}0.013 \\
(0.019)\end{array}$ & $\begin{array}{c}0.013 \\
(0.024)\end{array}$ & $\begin{array}{c}0.038 \\
(0.028)\end{array}$ & $\begin{array}{c}0.012 \\
(0.024)\end{array}$ & $\begin{array}{c}0.028 \\
(0.029)\end{array}$ \\
\hline Tang $* \mathrm{E}_{2 \mathrm{t}}$ & $\beta_{\mathrm{m} 4}$ & $\begin{array}{c}0.003 \\
(0.034)\end{array}$ & $\begin{array}{c}0.003 \\
(0.060)\end{array}$ & $\begin{array}{c}0.011 \\
(0.071)\end{array}$ & $\begin{array}{c}0.003 \\
(0.060)\end{array}$ & $\begin{array}{c}0.002 \\
(0.076)\end{array}$ \\
\hline Ind $* \mathrm{E}_{2 \mathrm{t}}$ & $\beta_{\mathrm{m} 5}$ & $\begin{array}{c}0.500 * * * \\
(0.056)\end{array}$ & $\begin{array}{c}0.500 * * * \\
(0.086)\end{array}$ & $\begin{array}{c}0.428 * * * \\
(0.082)\end{array}$ & $\begin{array}{c}0.500 * * * \\
(0.086)\end{array}$ & \\
\hline Vol $* E_{2 t}$ & $\beta_{\mathrm{m} 6}$ & $\begin{array}{c}-0.165^{* * * *} \\
(0.028)\end{array}$ & $\begin{array}{c}-0.165^{* * * *} \\
(0.035)\end{array}$ & $\begin{array}{c}-0.208 * * * \\
(0.036)\end{array}$ & $\begin{array}{c}-0.165^{* * *} * \\
(0.035)\end{array}$ & $\begin{array}{c}-0.235 * * * \\
(0.039)\end{array}$ \\
\hline $\operatorname{Size}^{*} \mathrm{E}_{2 \mathrm{t}} * \mathrm{D}_{\mathrm{i}}$ & $\beta_{\mathrm{j} 1}$ & $\begin{array}{c}-0.022 * * \\
(0.011)\end{array}$ & $\begin{array}{l}-0.022 \\
(0.014)\end{array}$ & $\begin{array}{c}0.023^{* *} \\
(0.011)\end{array}$ & $\begin{array}{l}-0.022 \\
(0.014)\end{array}$ & $\begin{array}{c}-0.013 \\
(0.011)\end{array}$ \\
\hline Prof $* E_{2 t} * D_{i}$ & $\beta_{\mathrm{j} 2}$ & $\begin{array}{c}-1.859 * * * \\
(0.453)\end{array}$ & $\begin{array}{c}-1.859 * * * \\
(0.555)\end{array}$ & $\begin{array}{c}-2.292 * * * \\
(0.576)\end{array}$ & $\begin{array}{c}-1.862 * * * \\
(0.555)\end{array}$ & $\begin{array}{c}-2.443 * * * \\
(0.594)\end{array}$ \\
\hline Grow $* \mathrm{E}_{2 \mathrm{t}} * \mathrm{D}_{\mathrm{i}}$ & $\beta_{\mathrm{j} 3}$ & $\begin{array}{l}-0.054^{*} \\
(0.031)\end{array}$ & $\begin{array}{l}-0.054 \\
(0.037)\end{array}$ & $\begin{array}{c}-0.073 * \\
(0.039)\end{array}$ & $\begin{array}{l}-0.053 \\
(0.037)\end{array}$ & $\begin{array}{l}-0.063 \\
(0.040)\end{array}$ \\
\hline Tang $* \mathrm{E}_{2 \mathrm{t}} * \mathrm{D}_{\mathrm{i}}$ & $\beta_{\mathrm{j} 4}$ & $\begin{array}{c}-0.046 \\
(0.061)\end{array}$ & $\begin{array}{c}-0.046 \\
(0.096)\end{array}$ & $\begin{array}{c}-0.049 \\
(0.105)\end{array}$ & $\begin{array}{c}-0.046 \\
(0.096)\end{array}$ & $\begin{array}{l}-0.039 \\
(0.109)\end{array}$ \\
\hline Ind $* E_{2 t} * D_{i}$ & $\beta_{\mathrm{j} 5}$ & $\begin{array}{c}-0.329 * * * \\
(0.126)\end{array}$ & $\begin{array}{c}-0.329 * * \\
(0.166)\end{array}$ & $\begin{array}{l}-0.253 \\
(0.165)\end{array}$ & $\begin{array}{c}-0.329 * * \\
(0.166)\end{array}$ & $\begin{array}{c}0.173 \\
(0.145)\end{array}$ \\
\hline $\mathrm{Vol} * \mathrm{E}_{2 \mathrm{t}} * \mathrm{D}_{\mathrm{i}}$ & $\beta_{\mathrm{j} 6}$ & $\begin{array}{c}0.177 * * * \\
(0.046)\end{array}$ & $\begin{array}{c}0.177 * * * \\
(0.053)\end{array}$ & $\begin{array}{c}0.223 * * * \\
(0.054)\end{array}$ & $\begin{array}{c}0.177 * * * \\
(0.053)\end{array}$ & $\begin{array}{c}0.251^{*} * * \\
(0.057)\end{array}$ \\
\hline Constant & & $\begin{array}{c}1.663 \\
(11.568) \\
\end{array}$ & $\begin{array}{c}1.663 \\
(10.350) \\
\end{array}$ & $\begin{array}{l}18.930^{*} \\
(10.892)\end{array}$ & $\begin{array}{c}-0.679 \\
(10.498) \\
\end{array}$ & $\begin{array}{l}20.193^{*} \\
(11.649) \\
\end{array}$ \\
\hline $\begin{array}{l}\text { Obs } \\
\mathrm{R}^{2}\end{array}$ & & $\begin{array}{c}1465 \\
0.353\end{array}$ & $\begin{array}{c}1465 \\
0.353\end{array}$ & $\begin{array}{c}1465 \\
0.301\end{array}$ & $\begin{array}{c}1465 \\
0.344\end{array}$ & $\begin{array}{c}1465 \\
0.242\end{array}$ \\
\hline
\end{tabular}

Notes: Standard deviations in brackets; ***,*** indicate significance at 1\%, 5\% and 10\%, respectively. 
Results from models 1 and 2 show that political patronage explains the differences in leverage between the two groups of protected and unprotected enterprises through coefficient $\beta_{1}=0.121>0$, statistically significant at $1 \%$ level. This result is consistent with the initial statistical analysis and results of previous studies, that businesses with the strong support from the government are more likely to access to loans than non-connected ones ([4]; [1]; [21]; [7]; [14]). Next is the coefficient $\beta_{2}$ of dummy variable $E_{1}$ representing the crisis period, $\beta_{2}<0$ showing that the leverage level of enterprises in this period tends to decrease sharply. Accordingly, when the economy falls into crisis, all businesses face difficulties in borrowing due to high bankruptcy costs. However, the estimation results also show that there is no difference in the level of decline in debt ratio between the two groups of enterprises because the coefficient $\beta_{3}$ of the interaction variable $\mathrm{E}_{1} * \mathrm{D}$ is not statistically significant. From this result it can be concluded that political protection does not work to support businesses to increase access to loans when a crisis occurs. In addition, the estimation model also calculates the degree of impact of each basic factor on leverage in the crisis period through the coefficients $\beta 1$ of the interaction variables. From the results, most of the coefficients are not statistically significant except interactive variables Size $* \mathrm{E}_{1}$ and $\mathrm{Vol}^{*} \mathrm{E}_{1}$, synonymous with crisis periods such as profit, investment opportunities and assets. fixedness is less considered when managers decide capital structure compared to the pre-crisis period. Instead, the scale of enterprises and the fluctuation of cash flow are more concerned, expressed through the coefficients $\beta_{11}>0$ and $\beta_{16}<0$. This shows that when the financial crisis occurs, businesses with business difficulties increase business risks, the financial institutions or creditors mostly pay attention to the size of the business and cash flow fluctuations to make credit decisions without regard to other characteristics such as the precrisis period. However, administrators still employ the industry average leverage to determine the debt ratio of businesses even when the crisis occurs.

Coefficient $\beta_{\mathrm{k}}$ is regarded to assess whether the impact of the economic crisis changes the ability to predict leverage of specific factors in protected businesses? The results show that most of the coefficients are insignificant, except the Ind ${ }^{*} \mathrm{E}_{1} * \mathrm{D}$ is statistically significant. This suggests that businesses in this crisis period have a leverage ratio towards industry leverage but for businesses that are protected by politics, the sector leverage ratio is not much affected. The reason is that in the turbulent crisis period, enterprises with political protection will receive financial support from the state, mainly depending on the state's financing policy, so the direction to leverage the industry is no longer available. too important ([2]).

The following concern is the levels of leverage of businesses in the post-crisis period and the differences in capital structure between politically connected enterprises and non-connected ones. Negative coefficient $\beta_{22}$ indicates that compared with the pre-crisis period (2005 - 2007), the leverage level of all businesses decreased significantly. This result is similar to the study of [3] in Malaysia. The lower debt ratio reflects the development of the equity market and the problems of agency costs have decreased. Positive and statistically significant coefficient $\beta_{33}$ points to the reality that politically connected businesses use more debt than those without state sponsorship.

Coefficient $\beta_{\mathrm{m}}$ determines the level of impact of each factor on leverage in the post-crisis period. Research results show that the factors including scale, profit, the level of fluctuation of cash flow have a degree of influence on the decision of capital structure of enterprises like the period before crisis. Finally, the coefficients $\beta_{\mathrm{j}}$ represent the difference in the impact of each factor on leverage between the unprotected enterprise and the protection of the financial crisis. The results showed that only the tangible asset factor was found no evidence that there was a difference, while the remaining elements showed differences in the recovery period.

Next is the result of model 3, when the dummy variables $E_{1}$ and $E_{2}$ are excluded from the estimation equation to consider the effect of unobserved time elements. The results in column 3 of Table 2 show that there is no difference in the values of the coefficients $\beta_{1}$ and $\beta_{\mathrm{k}}$, which means that separate effects of unobservable time such as institutions and economic cycles are taken into account in the model, the difference in leverage between connected and non-connected enterprises still exists and the predictability of specific elements remains unchanged. However, when considering the coefficients $\beta_{\mathrm{m}}$ and $\beta_{\mathrm{j}}$ in model 3 , in the post-crisis recovery period, the predictability of six basic factors seems better than the previous period since coefficient $\beta_{\mathrm{m}}$ is positive and statistically significant. In contrast, the values of the coefficient 
$\beta_{\mathrm{j}}$ is positive for the interaction variables $\operatorname{Size}^{*} \mathrm{E}_{2} * \mathrm{D}$ and $\mathrm{Vol}{ }^{*} \mathrm{E}_{2} * \mathrm{D}$. From this result, it is clear that politically connected enterprises are less affected by macro factors, typical characteristics of the economy, thus the leverage levels of these businesses remain less volatile. Results obtained from model 5 are similar to model 3, indicating that sector-specific determinants at each stage might contribute to the financing decision making of the non-connected businesses at a stronger levels than politically connected ones. Finally, results of model 4 (which derives from model 2, yet eliminates dummy variable D to justify the impact of specific characteristics of enterprises) are similar to model 2. Therefore, it is concluded that the leverage level of enterprises is fully reflected through five characteristic factors, viz. scale, profit, investment opportunities, profit volatility and fixed assets.

\section{CONCLUSIONS}

This paper seeks to examine the impact of political patronage on the capital structure decisions of enterprises under exogenous shock. Applying DID approach, our results reveal that politically patronised businesses, thanks to the state endorsement in credit mobilization, tend to have higher degrees of financial leverage than those without state support. However, differences between the two groups decreased as during the financial crisis and the recovery periods. During the 2008-2009 financial period, all businesses cut their debt levels, where political patronage did not have significant effect. The reason behind this is primarily due to the financial crisis causing systemic risks to increase, under which the government is afraid that capital support for businesses might possibly worsen the budget deficit, thus, the degrees of patronage decreases. Turning into the post-crisis period, businesses continued to reduce their debt holdings as in the development phase of the equity market, agency costs start reducing and equity capital becomes far more preferable. In addition, we found evidence that the leverage levels of politically patronised firms are less likely to be affected by unobservable characteristic factors such as institutions and economic cycles than firms without political connection. Therefore, as there are transformations in the economic situation, politically patronised firms tend to have more stable levels of leverage than nonconnected ones.

As Vietnamese economy has been en route for greater integration with the global economy, state incentives for typical enterprises would be gradually diminishing with commitments to establishing equality in the business community. Under the circumstances, it is essential that patronised businesses achieve satisfactory resolution for not falling into difficulties due to lack of capital.

\section{REFERENCE}

[1] Bliss, M.A., \& Gul, F. A. (2012). Political connection and the cost of debt: Some Malaysian evidence. Journal of Banking and Finance, 36, 1520-1527.

[2] Deesomsak, R., Paudyal, K., \& Pescetto, G. (2004). The determinants of capital structure: Evidence from the Asia Pacific region. Journal of Multinational Financial Management, 14, 387-405.

[3] Ebrahim, M. S., \& Mathur, I. (2013). On the efficiency of the UPREIT organizational form: Implications for the sub-prime crisis and CDO's. Journal of Economic Behaviour and Organization, 85, 286-305.

[4] Faccio, M. (2006). Politically-connected firms. American Economic Review, 96, 369-386.

[5] Faccio, M., Masulis, R. W., \& McConnell, J. J. (2006). Political connections and corporate bailouts. The Journal of Finance, 61(6), 2597-2635.

[6] Fisman, R. (2001). Estimating the value of political connections. American Economic Review, 91, $1095-1102$.

[7] Fraser, D. R., Zhang, H., \& Derashid, C. (2006). Capital structure and political patronage: The case of Malaysia. Journal of Banking and Finance, 30, 1291-1308

[8] Gomez, E. T., \& Jomo, K. S. (1997). Malaysia's political economy: Politics, patronage and profits. Cambridge: Cambridge University Press. 
[9] Goldman, E., Rocholl, J., \& So, J. (2013). Politically connected boards of directors and the allocation of procurement contracts. Review of Finance, 17(5), 1617-1648.

[10] Harrison, B. A. R. R. Y., \& Widjaja, T. W. (2013). Did the financial crisis impact on the capital structure of firms?. Discussion Papers in Economics, 5.

[11] Johnson, S., \& Mitton, T. (2003). Cronyism and capital controls: Evidence from Malaysia. Journal of Financial Economics, 67, 351-382.

[12] Khwaja, A. I., \& Mian, A. (2005). Do lenders favour politically connected firms? Rent provision in an emerging financial market. Quarterly Journal of Economics, 120, 1371-1411.

[13] Leuz, C., \& Oberholzer-Gee, F. (2006). Political relationships, global financing and corporate transparency: Evidence from Indonesia. Journal of Financial Economics, 81, 411-439.

[14] Li, A., \& Xia, X. (2013). Political Connections, Financial Crisis and Firm's Value: Evidence from Chinese Listed Firms. International Journal of Business and Management, 8(18), 63.

[15] Li, H., Meng, L., Wang, Q., \& Zhou, L. A. (2008). Political connections, financing and firm performance: Evidence from Chinese private firms. Journal of development economics, 87(2), 283-299.

[16] Lim, T. C., Chai, R., Zhao, D., \& Lim, X. Y. (2012). Capital structure and political patronage: Evidence from China. American Journal of Business and Management, 1(4), 177-182.

[17] Mitchell, H., \& Joseph, S. (2010). Changes in Malaysia: Capital controls, prime ministers and political connections. Pacific-Basin Finance Journal, 18, 460-476.

[18] Sapienza, P. (2004). The effects of government ownership on bank lending. Journal of financial economics, 72(2), 357-384.

[19] Shleifer, A., \& Vishny, R. W. (1994). Politicians and firms. Quarterly Journal of Economics, 109, $995-1025$.

[20] Wu, W., Wu, C., \& Rui, O. M. (2012). Ownership and the value of political connections: Evidence from China. European Financial Management, 18(4), 695-729.

[21] Yeh, Y. H., Shu, P. G., \& Chiu, S. B. (2013). Political connections, corporate governance and preferential bank loans. Pacific-Basin Finance Journal, 21(1), 1079-1101.

[22] Fu, J., Shimamoto, D., \& Todo, Y. (2017). Can firms with political connections borrow more than those without? Evidence from firm-level data for Indonesia. Journal of Asian Economics, 52, 45-55.

[23] Okuda, H., \& Nhung, L.T.P. (2011). Fundraising Behaviors of Listed Companies in Vietnam: An Estimation of the Influence of Government Ownership. Center for Economic Institutions.

[24] Tee, C.M. (2018). Political connections and the cost of debt: Re-examining the evidence from Malaysia. Journal of Multinational Financial Management, 46, 51-62.

[25] Vy, L.T.P., \& Nguyet, P.T.B. (2015). The impact of state ownership on financial decisions: Empirical evidence in Vietnam. Journal of Development and Integration, 22 (32), 50-57

Received on February $1^{\text {st }}$, 2019

Accepted on March 25 $5^{\text {th }}, 2019$ 